\title{
Classification of Building Structures of Mining Plants with Regard to Calculating Property Tax ${ }^{* *}$
}

\section{Introduction}

Pursuant to article 2 section 1 of the Act on Local Taxes and Fees [3], land, buildings or portions thereof, structures or portions thereof, relating to conducting business activities are subject to real property tax. Classification of building structures to the above categories should be performed on the basis of the Construction Law [4], in accordance with its article 3.

Classification of assets of industrial plants with regard to calculating property tax meets with difficulties arising from the imprecise and inconsistent legislation [1]. In the case of mining plants, this particularly refers to mine workings and objects located under the surface of the ground.

According to the Constitutional Court's judgment of 13 September 2011 [7], article 2 of the Act on Local Taxes and Fees [3] does not apply to underground mine workings, however, it can refer to objects located in these workings. In their statement of reasons, the Constitutional Court set out the general criteria for classification for such objects, based on the Construction Law [4], taking into account the provisions of the Geological and Mining Law [5, 6].

They prove that the interpretation of specific cases requires a detailed analysis both in terms of construction and process engineering.

This article discusses the problems associated with carrying out such an analysis, and presents the resulting conclusions.

* AGH University of Science and Technology AGH University of Science and Technology, Faculty of Mining Surveying and Environmental Engineering, Krakow, Poland

** This article was prepared within the scope of the AGH UST statutory research no. 11.11 .150 .005 


\section{Legal Basis for the Classification of Building Structures with Regard to Calculating Property Tax}

For municipalities, the Construction Law [4] constitutes the basis for classifying objects with regard to calculating property tax. In the analyzed case, the provisions contained in the Act on Local Taxes and Fees [3] and in the Geological and Mining Law $[5,6]$ are also of great importance. In order to carry out an appropriate classification of assets of industrial plants, the meaning of the basic terms used in particular laws must be clearly defined first.

Pursuant to the Construction Law, article 3 [4] a building structure is:

- a building with installations and technical equipment,

- a structure which is a technical and utility whole, together with installations and equipment,

- an object of landscape architecture.

In particular:

- a building - such a building structure that is permanently affixed to land, separated from the space by wall barriers, and has foundations and a roof;

- a structure - any building structure which is not a building or an object of landscape architecture, such as: linear objects, bridges, viaducts, overpasses, tunnels, culverts, technical networks, earthworks, tanks, freestanding industrial installations or technical equipment, sewage treatment plants, retaining structures, pedestrian crossings on ground level and underground ones, public utilities, and also construction parts of technical equipment (boilers, industrial furnaces), as well as foundations for machinery and equipment, as technically distinct portions of the objects that make up the utility whole.

In the analyzed case, the following definitions are also of some importance:

- a linear object - a building structure, whose characteristic parameter is the length, in particular a road with exits, a railway, a water supply pipeline, a canal, a gas pipeline, a heat pipeline, a pipeline, an electricity power line and a overhead power transmission line, a cable line (overhead and placed directly in the ground, an underground line), dikes and cables in sewage system, where the cables installed in it do not constitute a building structure nor part thereof, nor a building's infrastructure;

- building's infrastructure - technical equipment connected with a building structure, providing for a possibility to use the object according to its intended purpose, such as utilities and installation equipment, including those for treatment or the accumulation of sewage, as well as crossings, fences, parking places and sites under garbage enclosures.

The Act on Local Taxes and Fees, article 2 [3] provides a slightly different definition of a structure: a structure is an object, within the meaning of the Construction Law, which is not a building or an object of landscape architecture, as well as a building's 
infrastructure under the provisions of the Construction Law, associated with a building structure, which provides for a possibility to use the object as intended.

According to the Geological and Mining Law of 1994 [5]:

- mining plant building structures are building structures within the meaning of the Construction Law, entirely located on the surface of the earth, used for the direct exploitation of minerals from deposits (article 58);

- a mine working is the space in a parcel of land or in the rock mass, created as the result of mining activities (article 6 clause 10).

However, according to the new Geological and Mining Law of 2011 [6]:

- a mining plant building structure is a mining plant object, located outside the underground mine workings, which is a building structure within the meaning of the Construction Law [4], used directly to perform activities regulated by the Act relating to the exploitation of minerals from deposits, and in underground coal mines, together with the technology associated with the preparation of the extracted minerals for sale, the underground injection storage of the substances, or the underground storage of waste (article 6.1, clause 4);

- a mine working - article 6.1, clause 17, the same definition as in [5].

The above quotations reveal discrepancies in the definitions of the terms which are essential for the classification of fixed assets of mines. In particular, this refers to the concept of a "structure" in the Construction Law [4] and in the Act on Local Taxes and Fees [3], and a change in the meaning of the term "mining plant building structure" in the new version of the Geological and Mining Law [6].

\section{Analysis of the Problem of Classifying Building Structures of Mining Plants on the Basis of the Constitutional Court's Judgment}

An additional, important source of information regarding the classification of the taxable assets of mining plants is the Constitutional Court's judgment of 13 September 2011 [7]. In this judgment, it was decided that article 2 section 1 clause 3 , in connection with article 1a section 1 clause 2 of the Act on Local Taxes and Fees [3], understood in such a way that it does not apply to underground mine workings but it may relate to objects and equipment located in these workings, is consistent with the principle of legality of terms in tax regulations and the principle of proper legislation based on article 217 in connection with article 84 and article 2 of the Constitution of the Republic of Poland.

In the statement of reasons of the Constitutional Court's judgment [7], reservations are formulated to ambiguous relationships that exist between the concepts of a building structure, building's infrastructure and some of the names of objects that are examples of structures. It is stated, for example, that if in article 3 clause 1 sub-clause a and b of the Construction Law [4], the legislator distinguishes between (technical) equipment 
and installations, and building's infrastructure is a special type of (technical) equipment, then we must accept that installations are not building's infrastructure.

In conclusion of their judgment [7], the Constitutional Court stated that the analyses [4-6] led to findings that there were no persuasive arguments which were generally against a possibility to consider structures located in mine workings, including underground mine workings, to be building structures, if only the analyzed objects could be classified:

- as building structures related to conducting business activity, in the form of structures within the meaning of [4], being also structures in terms of [3], or

- as portions of building structures related to conducting business activity, considered to be building's infrastructure within the meaning of [4], being also structures in terms of [3].

The Constitutional Court [7] shared a view that in each tax case regarding infrastructure located in underground mine workings, it was necessary to determine exactly which of the objects and equipment could be classified as structures within the meaning of the Act on Taxes and Fees [3], which would allow us to avoid the risk of relying on dubious generalizations in this regard. Given a large diversity of objects and equipment located in underground mine workings, it is necessary to consider precisely whether each of these objects and equipment, their groups, or the entire analyzed infrastructure are attributable to the names of the structures designated in the Construction Law [4], which does not seem an easy task at all. If the assignment of individual objects and equipment located in underground mine workings to the categories of structures specified in [4] fails, it will be necessary to determine whether the analyzed objects and equipment can be classified as building's infrastructure within the meaning of [4], which are also structures in terms of [3].

When defining a building structure, which specific technical equipment remains connected with, and examining whether it provides a possibility to use such a building structure for its intended purpose, two facts should be taken into account:

1) If the underground mine working, considered to be a space (the working in a physical sense) is not a building structure in terms of [4], and the underground mine working considered to be technical infrastructure (the working in a technical sense) is not a building structure, at least in terms of [3], any attempts to classify any equipment as building's infrastructure by demonstrating its necessity for the functioning of the working is unfounded.

2) At least in some cases, seeking a connection between technical equipment located in underground mine workings with ground-based building structures may raise some doubts. A connection between building's infrastructure and a building structure to ensure a possibility to use such an object as intended, should not be construed so broadly that it would include a guarantee of an opportunity to perform economic tasks by a given object, arising from the fact that it belongs to a particular enterprise which, in the analyzed case, is the mining plant.

As an example in [7], it is stated that the equipment used to supply fresh air to mine workings (air duct lines), pipelines for water supply and drainage, or roof 
supports, although they determine the operation of underground mine workings, and thus, in the economic terms, justify the existence of ground-based building structures which are part of a mining plant, in no way does this equipment determine a possibility to use these objects as intended. The question, whether it can be considered building's infrastructure, including building's infrastructure connected with ground-based building structures, still remains open.

\section{Classification of Objects Located in Mining Plants}

This chapter presents the principles of classifying assets of mining plants on the basis of the Construction Law [4], pursuant to the Act on Local Taxes and Fees [3], Geological and Mining Law [5, 6], as well as taking into account the findings of the Constitutional Court's judgment [7].

Four categories were specified, which these objects can potentially be assigned to, and examples of classifications, e.g. of cable lines and pipelines located in various places in a mining plant were provided (Figs 1-4):

1) a building,

2) a structure,

3) industrial installation or technical equipment,

4) mine workings.

A building (Fig. 1) is a cubature object having a foundation, walls and a roof, which is an independent building structure, for example: workshop buildings, electrical switchgear system buildings, social buildings.

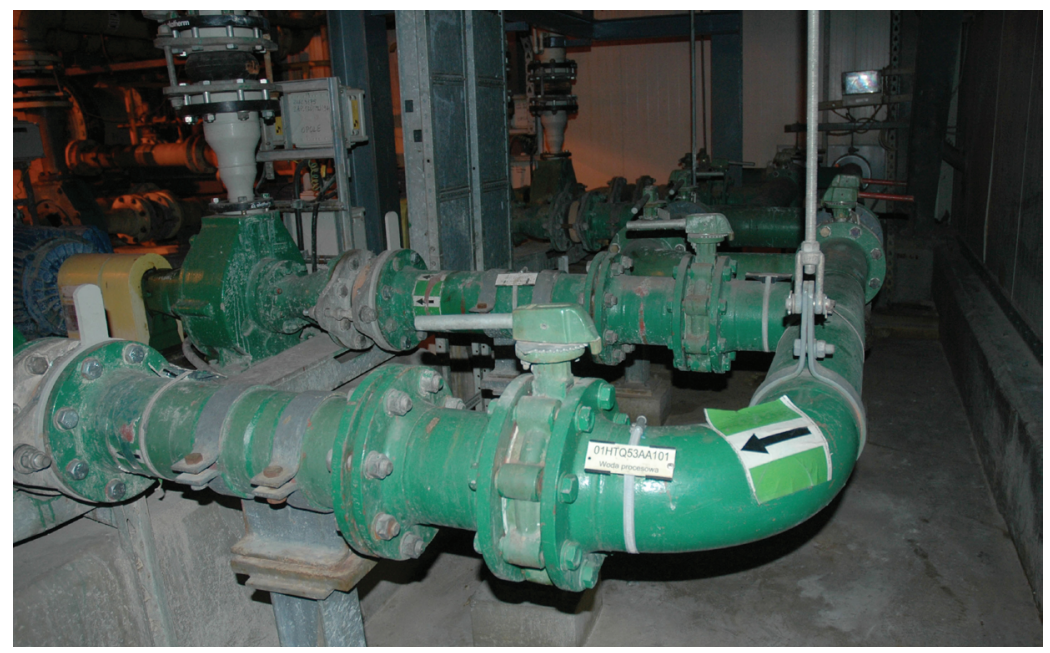

Fig. 1. Pump house with lighting installation and foundations under machinery (building), where pumps are located (technical equipment) and pipelines (technological installations)

Source: [2] 
A structure (Figs 2, 3) is characterized by the fact that it is permanently affixed to land and it must be an independent, free-standing object.

A structure, within the meaning of [3], can be considered [7]:

- only structures expressly stated in article 3 clause 3 [4], in the other provisions of this Act or in the Appendix thereto, which, together with the installations and equipment, are a building structure referred to in article 3 clause 1 subclause b [4], that is, provided that they make up the technical and utility whole;

- only technical equipment specified in article 3 clause 9 [4], or in other provisions of this Act, or in Appendix thereto, which - if the analyzed equipment has not been expressly stated - requires a demonstration that this equipment provides a possibility to use a building structure as intended, but excluding:

- building's infrastructure connected with building structures in the form of structures within the meaning of [4], the building structures which can not be classified as structures in terms of [3], and

- building's infrastructure connected with building structures in the form of objects of landscape architecture, with a reservation that the building's infrastructure within the meaning of [4] are not installations; having also in mind that it is not excluded that the status of individual objects and equipment will also be co-decided about by other statutory regulations, which are supplementary to, modifying or further specifying the Construction Law.

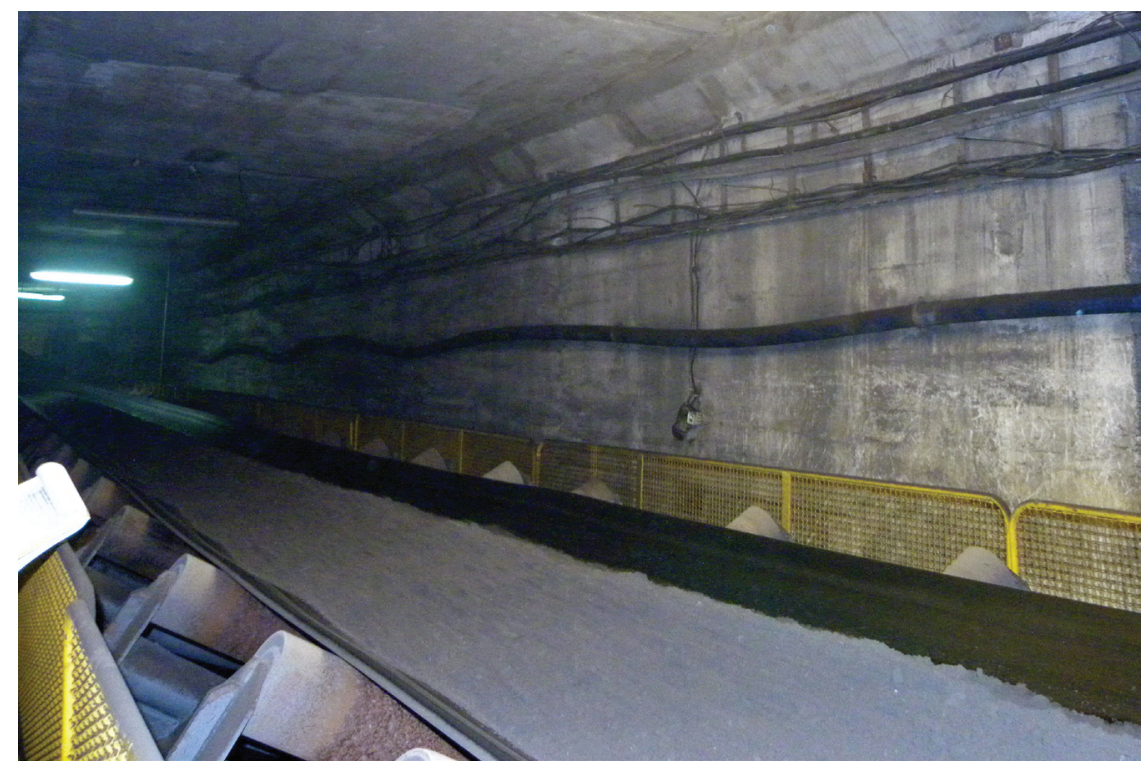

Fig. 2. Transportation tunnel with lighting installation (structure), where a conveyor belt (technical equipment) is located and cable lines (technological installations)

Source: [2] 


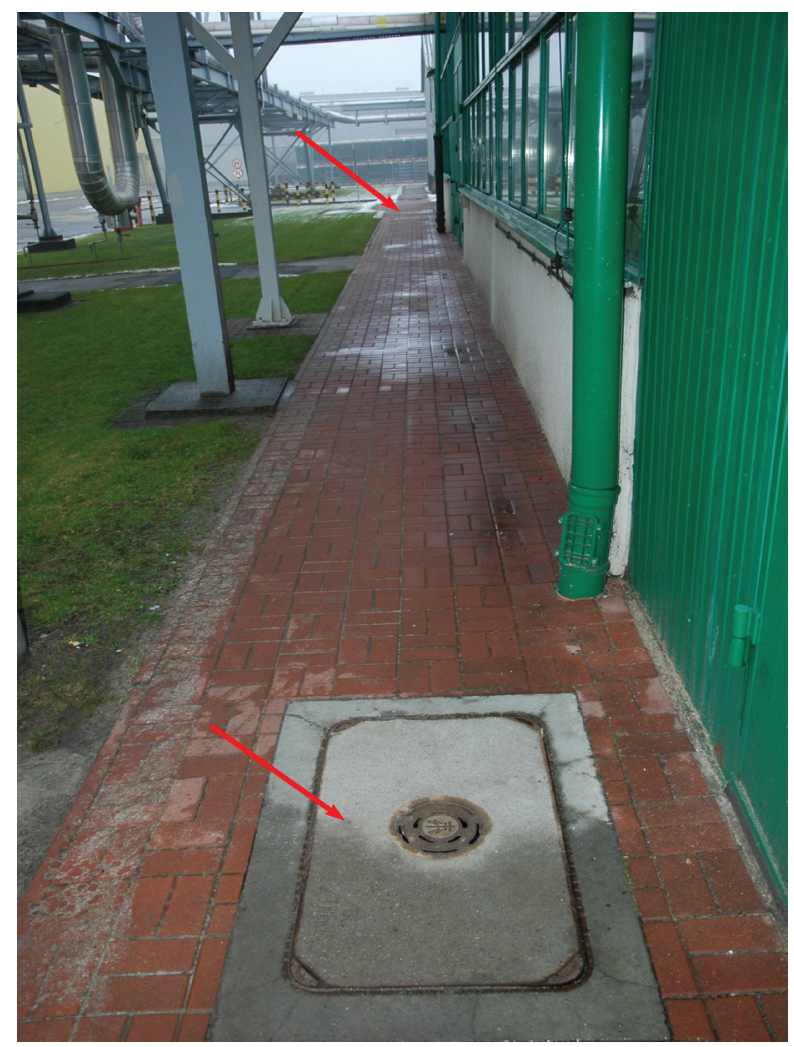

Fig. 3. Cable line between wells (structure), placed in the ground along the wall of the compressor building

Source: [2]

Industrial installation or technical equipment (Figs 1, 2, 4) located in mining plants, fixed to special foundations, supporting structures, or to working roof supports, that is not a structure or building's infrastructure within the meaning of the Construction Law . These are industrial installations and technical equipment involved in the production process carried out in a mine, which do not serve to ensure a possibility to use building structures. In the case of objects located in mining plants, they include: cable lines, pipelines, conveyor belts and scraper conveyors, overhead cranes, cranes, electrical switchboards, transformers, batteries, motors, fans, as well as roof supports, heading machines, crushers, drills, roof bolting machines, locomotives, transport cabins, hoists, power generators, pumps and other specialized technical equipment.

Mine workings (Fig. 4), defined as the space in a parcel of land or in the rock mass, created as the result of mining activities, it is not a building structure within the meaning of the Construction Law [4]. 
It should be noted that, in accordance with the Act on Local Taxes and Fees, from the above list only buildings, as well as structures and building's infrastructure shall be subject to property tax.

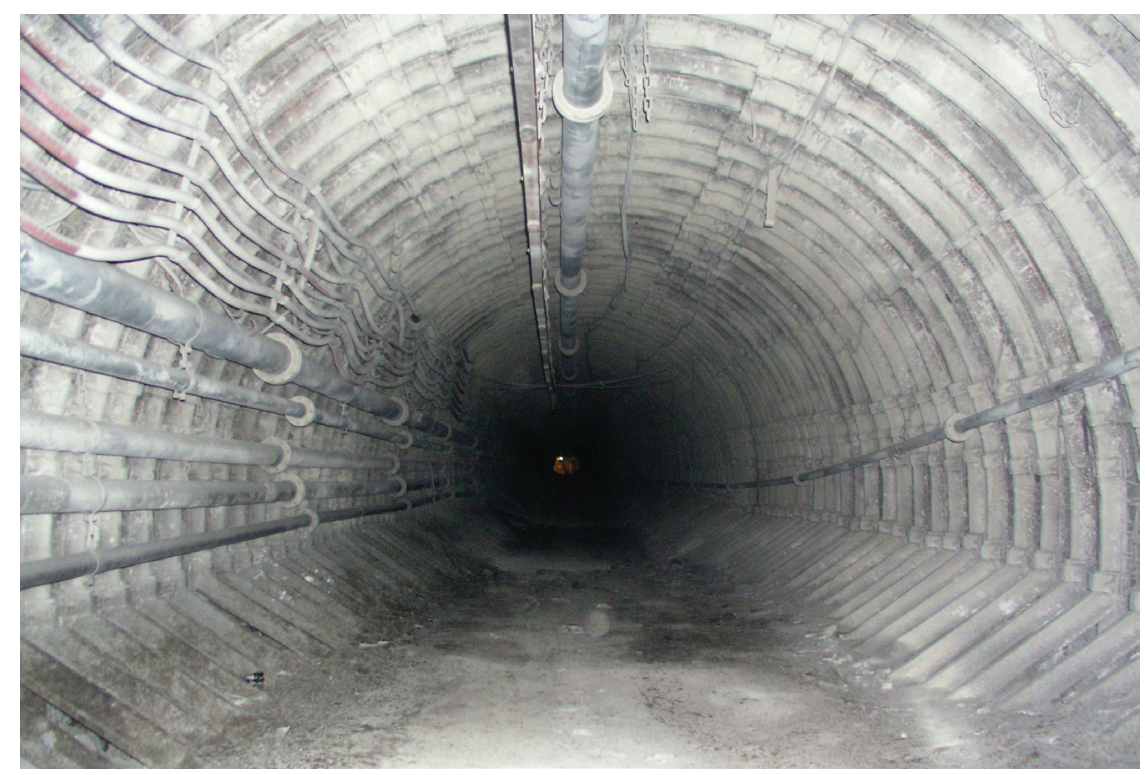

Fig. 4. Excavation corridor with roof support (mine working), where the suspended railway is located (technical equipment), drainage and fire protection pipeline, as well as power cables (technological installations)

Source: [2]

\section{Summary}

Classification of the assets of mining plants with regard to calculating property tax requires a detailed analysis in the legal, construction and process engineering aspects.

Determining correct rates of the tax on assets related to conducting economic activity in mining plants faces problems arising from the imprecise and inconsistent provisions contained in the legislation: the Construction Law, the Act on Local Taxes and Fees and the Geological and Mining Law.

Particular difficulties arise in the case of objects located in mine workings. The judgment of the Constitutional Court of 2011 allowed to classify these objects as structures or building's infrastructure. When classifying technical equipment as building's infrastructure, a building structure, which it is connected with, should be specified. 
In turn, when defining a building structure, which particular technical equipment remains connected with, it must be demonstrated that it provides an opportunity to use this object in accordance with its intended purpose.

In accordance with the constitutional requirements, unclear tax regulations shall not be interpreted to the detriment of taxpayers.

\section{References}

[1] Firek K., Oruba R., Wodyński A.: Classification of Building Structures Located in Industrial Plants with Regard to Calculating Property Tax. Geomatics and Environmental Engineering, vol. 8, no. 1, 2014, pp. 15-20.

[2] Opinie techniczne dotyczace kwalifikacji na gruncie ustawy Prawo budowlane składników majatku zakładów przemysłowych. Akademia Górniczo-Hutnicza im. Stanisława Staszica w Krakowie, Wydział Geodezji Górniczej i Inżynierii Środowiska, Katedra Geodezji Inżynieryjnej i Budownictwa, Kraków 2011, 2012, 2013 [unpublished].

[3] Ustawa z dnia 12 stycznia 1991 r. o podatkach i oplatach lokalnych (with amendments). Dz. U. 2002, nr 9, poz. 84.

[4] Ustawa z dnia 7 lipca 1994 r. - Prawo budowlane. Dz. U. nr 89, poz. 414 with amendments, unified text: 2.10.2013. Dz. U. 2013, poz. 1409.

[5] Ustawa z dnia 4 lutego 1994 - Prawo geologiczne i górnicze. Dz. U. nr 27, poz. 96.

[6] Ustawa z dnia 9 czerwca 2011 - Prawo geologiczne i górnicze. Dz. U. nr 163, poz. 981.

[7] Wyrok Trybunału Konstytucyjnego z dnia 13 września 2011 r. sygn. akt P 33/09. Dz. U. 2011, nr 206, poz. 1228. 